\title{
Upaya Mengembangkan Kreativitas Mahasiswa Melalui Pembelajaran Model Project Based Learning
}

\author{
Maya Masitha Astriani \\ Pendidikan Matematika Universitas Indraprasta PGRI \\ Jalan Nangka No. 58 C, Tanjung Barat, Jakarta Selatan \\ maya.masitha@gmail.com
}

\begin{abstract}
The purpose of this study is to describe the creativity of students through the learning of Project Based Learning. The research was conducted with One-Shot Case Study design with 28 students of Mathematics Education study program of Indraprasta PGRI University. The research data is obtained from analysis of report and product observation sheet. Data analysis with percentage technique and processed descriptively. The research result shows that by using project based learning the students are able to develop and produce mathematics props. It is proven by assessment report with range of the score of 80 - 85 and assessment product with range $82-88$ in the best criteria. It can be concluded that the learning with Project Based Learning model can improve student creativity.
\end{abstract}

Keywords - Project Based Learning, Creativity, Props

Abstrak - Tujuan penelitian ini adalah untuk mendeskripsikan kreativitas mahasiswa melalui pembelajaran Project Based Learning. Penelitian dilakukan dengan desain One-Shot Case Study dengan subjek penelitian 28 mahasiswa program studi Pendidikan Matematika Universitas Indraprasta PGRI. Data penelitian diperoleh dari analisis lembar observasi laporan dan produk. Analisis data dengan teknik persentase dan diolah secara deskriptif. Hasil penelitian menunjukkan bahwa dengan menggunakan pembelajaran proyek, mahasiswa telah mampu mengembangkan dan menghasilkan alat peraga matematika dengan baik, dibuktikan dari penilaian laporan dengan rentang skor yang diperoleh antara 80 sampai dengan 85 dan dari penilaian produk dengan rentang skor 82 sampai dengan 88 dengan kategori sangat baik. Dapat disimpulkan bahwa pembelajaran dengan model pembelajaran Project Based Learning dapat mengembangkan kreativitas mahasiswa.

Kata Kunci — Project Based Learning, Kreativitas, Alat Peraga

\section{PENDAHULUAN}

Pembelajaran matematika dewasa ini masih kurang memberi wawasan berpikir dan mengembangkan kemampuan berpikir kritis matematis. Pembelajaran matematika di sekolah hanya menekankan teori saja. Pesatnya perkembangan ilmu pengetahuan dan teknologi, ditambah implementasi penyempurnaan kurikulum yang belum secara komprehensif dipahami oleh para pelaku pendidikan diperkirakan turut menjadi penyebab kondisi ini Pembelajaran matematika yang lebih menekankan mengingat konsep semata, dengan cara yang tidak membekali pembelajaran sepanjang masa dan berorientasi masa depan juga turut memperparah kondisi tersebut.

Pendidikan calon guru pendidikan matematika di perguruan tinggi harus dapat mempersiapkan lulusannya agar siap dan handal dalam memasuki dunia kerja sesuai persyaratan yang ditentukan. Untuk menghadapi perubahan yang sangat cepat, maka proses pembelajaran khususnya matematika harus dipandu dengan kaidah-kaidah pendekatan ilmiah. Pendekatan ini bercirikan penonjolan dimensi pengamatan, penalaran, penemuan, pengabsahan, dan penjelasan tentang suatu kebenaran. Dengan demikian, proses pembelajaran harus dilaksanakan dengan dipandu nilai-nilai, prinsip-prinsip, dan kriteria keterampilan kerja ilmiah yang mumpuni.

Mengingat pentingnya keterampilan dan kerja ilmiah bagi keberhasilan calon guru khususnya dalam memelajarkan matematika, memupuk dan melatih mahasiswa menjadi bagian yang sangat penting dalam kurikulum Perguruan Tinggi. Hal ini juga sesuai dengan amanat kurikulum di program studi pendidikan matematematika Universitas Indraprasta PGRI, yang menyebutkan bahwa Capaian Pembelajaran (CP) lulusan mahasiswa S1 calon guru pendidikan matematika diantaranya adalah sarjana pendidikan matematika yang profesional, mandiri, inovatif, dan adaptif dengan perkembangan global serta dapat menghasilkan produkproduk riset pada bidang pendidikan matematika yang memiliki nilai inovatif dan berdaya guna. Terlihat bahwa aspek bekerja ilmiah menjadi salah satu hal penting yang perlu ditanamkan dalam diri calon guru pendidikan matematika.

Pada saat ini mahasiswa penting untuk diberikan keleluasaan mendapatkan pengalaman dan pemahamannya 
melalui aktivitas belajar. Aktivitas belajar mahasiswa dapat diperoleh melalui pengamatan dan penemuan atau eksperimen melalui proyek yang direncanakan dalam perkuliahan. Proyek perkuliahan dirancang untuk memberikan pengalaman kerja ilmiah bagi mahasiswa calon guru. Mereka dapat pula diberi keleluasan menggunakan berbagai peralatan dan media teknologi maupun informasi, kinerja teknik dan juga matematika. Tentunya hal tersebut akan menambah daya pikir dan keterampilan bekerja mahasiswa calon guru ketika praktik mengajar ataupun setelah lulus dari perguruan tinggi.

Salah satu upaya yang bisa dilakukan diantaranya adalah dengan memberikan suatu pembelajaran yang dapat membawa mahasiswa pada tingkat aktivitas berpikir kritis dan berpikir kreatif yang optimal. Pembelajaran yang dimaksud adalah dengan menerapkan pembelajaran ProjectBased Learning, yaitu pembelajaran berbasis proyek.

Dalam konteks pembelajaran matematika, pembelajaran Project Based Learning sangat potensial untuk memberikan pembelajaran yang bermakna, dapat melatih keterampilan berpikir kreatif melalui proyek dan memberikan pengalaman kepada mahasiswa bahwa matematika bermanfaat nyata bagi kehidupan, dan ada di sekitar mereka. Project Based Learning (PjBL) dapat mengembangkan keterampilan memecahkan dalam mengerjakan sebuah proyek yang dapat menghasilkan sesuatu [1].

Bertitik tolak dari permasalahan yang telah diuraikan, dalam upaya meningkatkan keterampilan berpikir kreatif mahasiswa calon guru pendidikan matematika, perlu diambil langkah-langkah untuk perbaikan kualitas perkuliahan yang tidak hanya membekali materi, namun juga melatih keterampilan kerja mahasiswa, maka perlu dilaksanakan pembelajaran yang kaya akan aktivitas bermakna dan melatih keterampilan berpikir kreatif yang ditunjukkan melalui kegiatan pengamatan (observasi), pengelompokan (klasifikasi), komunikasi dan penafsiran, mengajukan pertanyaan, serta merencanakan dan melaksanakan proyek yaitu dengan melakukan pembelajaran Project Based Learning (PjBL), maka penelitian ini perlu dilakukan.

Berdasarkan latar belakang di atas, maka rumusan masalah yang dikemukakan adalah "bagaimanakah upaya mengembangkan kreativitas mahasiswa melalui pembelajaran Project Based Learning (PjBL)?. Adapun tujuan penelitian untuk mendeskripsikan kreativitas mahasiswa melalui pembelajaran Project Based Learning (PjBL).

\section{KAJIAN PUSTAKA}

\section{A. Berpikir Kreatif}

Berpikir kreatif diartikan sebagai suatu kegiatan mental yang digunakan seseorang untuk membangun ide atau gagasan baru [2]. Selain itu, berpikir kreatif melibatkan logika dan intuisi secara bersama-sama [3]. Secara khusus dapat dikatakan berpikir kreatif sebagai satu kesatuan atau kombinasi dari berpikir logis dan berpikir divergen guna menghasilkan sesuatu yang baru [4].

Kreativitas merupakan kemampuan mengimajinasikan, menafsirkan dan mengemukakan gagasan serta usaha yang memiliki daya cipta untuk kombinasi baru dari unsur sebelumnya yang sudah ada sehingga diperoleh peningkatan kualitas siswa dalam pengembangan dirinya [5]. Sedangkan berpikir kreatif sebagai kombinasi antara berpikir logis dan berpikir divergen yang didasarkan pada intuisi tapi masih dalam kesadaran [6]. Ketika seseorang menerapkan berpikir kreatif dalam suatu praktik pemecahan masalah, suatu pemikiran divergen dapat menghasilkan banyak ide yang berguna dalam menyelesaikan masalah.

Peningkatan kemampuan berpikir kreatif dapat dilakukan melalui pembelajaran di kelas. Selama proses pembelajaran, guru dapat memanfaatkan materi yang dipelajari untuk mengembangkan atau meningkatkan kemampuan berpikir kreatif siswa.

\section{B. Model Project Based Learning (PjBL)}

Project Based Learning (PjBL) merupakan salah satu model pembelajaran yang mampu meningkatkan kreativitas siswa dalam pembelajaran yang mengintergrasikan dengan masalah nyata [7]. Penerapan model PjBL menuntut siswa menyelesaikan sebuah proyek yang ada dalam kehidupan sehari-hari, sehingga kreativitas siswa terasah. Proyek-proyek adalah tugastugas yang diberikan guru berdasarkan pertanyaan atau masalah yang menantang, melibatkan siswa dalam perancangan, pemecahan masalah, memberikan keputusan, atau menyelidiki aktivitas, memberikan hak secara otonomi selama periode waktu untuk mengumpulkan dan mengintegrasikan pengetahuan baru berdasarkan pengalaman siswa dalam beraktifitas secara nyata [8].

The George Lucas Educational Foundation, menetapkan langkah - langkah pelaksanaan PjBL dimulai dengan pertanyaan yang dapat memberi penugasan kepada siswa dalam melakukan aktivitas, yang kemudian dilakukan investigasi mendalam, seperti mengidentifikasi unsur yang ada dan yang ditanyakan. Selanjutnya mendesain perencanaan proyek dan penyusunan jadwal penyelesaian proyek, dimana perencanaan dilakukan secara kolaboratif antara guru dan siswa [9] . Perencanaan berisi aturan pelaksanaan kegiatan, pemilihan aktivitas yang dapat mendukung dalam menjawab pertanyaan mendasar, dengan cara menggunakan berbagai metode atau sumber yang mungkin untuk membantu penyelesaian masalah serta membuat penjelasan tentang pemilihan cara/ strategi menyelesaikan masalah, sehingga siswa diharapkan dapat memberikan banyak ide, cara atau saran serta siswa dapat menghasilkan beragam gagasan dan dapat melihat suatu masalah dari beragam sudut pandang/ pemikiran. 
Pembelajaran dengan PjBL, guru bertanggung jawab melakukan monitor terhadap aktivitas siswa selama menyelesaikan proyek, sehingga siswa mampu mengembangkan suatu gagasan dan menghasilkan hasil yang memuaskan. Menguji atau menilai hasil proyek juga perlu dilakukan untuk membantu guru dalam mengevaluasi kemajuan siswa dan memberi umpan balik tentang tingkat pemahaman yang sudah dicapai siswa. Pada akhir pembelajaran, perlu dilakukan refleksi terhadap aktivitas dan hasil proyek yang telah dilakukan dengan harapan dapat menerapkan dan menyelesaikan permasalahan-permasalahan lain dalam kehidupan sehari-hari.

\section{Alat Peraga}

Alat peraga adalah suatu alat yang dapat diserap oleh mata dan telinga dengan tujuan membantu guru agar proses belajar mengajar siswa lebih efektif dan efisien [10]. Alat peraga pembelajaran sebagai sarana komunikasi dan interaksi antara guru dan siswa dalam proses pembelajaran [11]. Alat peraga pembelajaran adalah sesuatu yang dapat digunakan untuk menyampaikan pesan sehingga dapat merangsang pikiran, perasaan, perhatian, minat serta perhatian siswa sehingga proses belajar mengajar terjadi.

Alat peraga merupakan media pembelajaran yang mengandung atau membawakan ciri-ciri konsep yang dipelajari [12]. Contoh: papan tulis, buku tulis, dan daun pintu yang berbentuk persegi panjang dapat berfungsi sebagai alat peraga pada saat guru menerangkan bangun geometri dalam persegi panjang. Fungsi utama alat peraga adalah untuk menurunkan keabstrakan dari konsep, agar siswa mampu menangkap arti sebenarnya dari konsep yang dipelajari.

Dengan melihat, meraba, dan memanipulasi alat peraga maka siswa mempunyai pengalaman nyata dalam kehidupan tentang arti konsep. Sedangkan sarana merupakan media pembelajaran yang fungsi utamanya sebagai alat bantu untuk melakukan pembelajaran. Dengan menggunakan sarana tersebut diharapkan dapat memperlancar pembelajaran. Contoh: papan tulis, jangka, penggaris, lembar tugas (LT), lembar kerja (LK), dan alat-alat permainan.

Alat peraga dapat digunakan secara efektif sebagai perantara antara sifat abstraksi matematika ke hal yang lebih nyata [13]. Penggunaan alat peraga akan cenderung untuk mempromosikan kemampuan pemecahan masalah dengan menyediakan alat kepada siswa-siswa ke situasi dunia nyata. Penggunaan alat peraga dianggap lebih abstrak dari situasi aktual namun kurang abstrak daripada simbol formal. Pentingnya penggunaan alat peraga agar keberhasilan belajar diukur dengan kadar pengalaman belajar yang diperoleh siswa tergantung perlakuannya dalam belajar, baik perlakuan guru atau aktivitas siswa saat belajar [14]. Oleh karena itu, keterampilan mahasiswa dalam memproduksi alat peraga sangat diperlukan terutama dengan menggunakan bahan bekas pakai melalui pembelajaran berbasis proyek.

\section{METODE PENELITIAN}

Subjek penelitian adalah mahasiswa program studi Pendidikan Matematika Universitas Indraprasta PGRI yang mengambil mata kuliah workshop matematika dengan jumlah 28 orang. Desain yang digunakan dalam penelitian adalah desain eksperimen One-Shot Case Study [15]. Pelaksanaannya dengan cara memberikan perlakuan dalam pembelajaran mata kuliah workshop matematika yang diikuti oleh mahasiswa program studi Pendidikan Matematika yang mengambil mata kuliah tersebut berupa pembelajaran berbasis proyek untuk membuat produk inovasi alat peraga matematika untuk kelas 9 SMP menggunakan bahan bekas pakai. Selanjutnya diobservasi hasilnya berupa kemampuan berpikir kreatif dan pengetahuan mahasiswa dalam memproduksi alat peraga matematika.

Adapun sintaks pembelajaran Project Based Learning adalah sebagai berikut: Pertama, orientasi mahasiswa terhadap proyek, memotivasi mahasiswa agar terlibat dalam penyelidikan; Kedua, organisasi mahasiswa untuk belajar, dosen membantu mahasiswa mengorganisasikan tugas belajar yang berhubungan dengan proyek yang dikaji; Ketiga, pembimbingan penyelidikan secara individual dan kelompok; Keempat, membantu mahasiswa dalam menyiapkan karya untuk dilaporkan; Kelima, membantu mahasiswa dalam melakukan refleksi dan evaluasi terhadap proses penyelidikan yang dilaksanakan [16].

Instrumen yang digunakan dalam penelitian ini adalah: a. nilai laporan akhir dengan menggunakan lembar penilaian laporan, dan b. nilai produk alat peraga matematika menggunakan lembar penilaian produk. Masing-masing data yang diperoleh kemudian dianalisis sesuai data yang diperoleh; a. nilai laporan akhir: menilai laporan dengan rentang skor 60-100, dan b. nilai produk alat peraga matematika. Karya inovatif mahasiswa dalam penelitian ini dinilai berdasarkan lembar penilaian untuk selanjutnya dihitung dengan rumus $\%=$ (skor yang diperoleh/skor total) x100. Kriteria penilaian kreativitas diadopsi dan dimodifikasi [17] seperti pada tabel 1 .

TABEL 1

Kriteria Kreatifitas Mahasiswa

\begin{tabular}{|c|c|}
\hline$\%$ & Kriteria Kreatifitas \\
\hline $81-100$ & Sangat tinggi \\
\hline $61-80$ & Tinggi \\
\hline $41-60$ & Sedang \\
\hline $21-40$ & Rendah \\
\hline $1-20$ & Sangat rendah \\
\hline
\end{tabular}

\section{HASIL PENELITIAN DAN PEMBAHASAN}

Penelitian ini dilakukan untuk mengetahui kreativitas mahasiswa dalam menghasilkan sebuah alat peraga matematika untuk kelas 9 SMP pada mata kuliah workshop matematika. Jumlah mahasiswa yang menjadi sasaran 
penelitian sebanyak 28 orang, dalam pelaksanaan pembelajaran dibagi dalam 7 kelompok dengan masingmasing anggota kelompok 4 orang. Data hasil penelitian yang telah dikumpulkan terdiri dari: penilaian laporan akhir kelompok dan penilaian produk alat peraga inovasi yang murah dengan memanfaatkan bahan bekas pakai. Selain itu, mahasiswa diminta untuk mendokumentasikan kegiatan mereka dalam video, sehingga terlihat mana mahasiswa yang terlibat dalam bekerja dan mana yang tidak. Berdasarkan video mahasiswa sudah terlibat aktif dalam kelompoknya masing-masing.

Setelah dilakukan proses pembelajaran Project Based Learning, secara berkelompok mahasiswa menyusun laporan akhir tertulis yang dipresentasikan di kelas, selanjutnya dilakukan penilaian dengan perolehan skor setiap kelompok. Alat peraga yang dikembangkan dinilai berdasarkan kriteria: originalitas, relevansi materi, tampilan produk, keawetan produk serta bahan yang digunakan.

Berdasarkan tabel 2, didapatkan hasil bahwa nilai laporan akhir kelompok $100 \%$ sudah tercapai dengan skor terkecil 80 dan nilai terbesar 86 . Sedangkan pada nilai alat peraga didapatkan skor terkecil 82 dan skor terbesar 88 . Berdasarkan analisis data, bahwa pembelajaran berbasis proyek dapat meningkatkan keterampilan mahasiswa dalam mengembangkan dan memproduksi alat peraga matematika dengan bahan bekas pakai.

TABEL 2

Judul-Judul Inovasi Alat Peraga

\begin{tabular}{|c|l|c|c|}
\hline \multirow{2}{*}{ Kelompok } & \multicolumn{1}{|c|}{ Alat Peraga } & \multicolumn{2}{|c|}{ Penilaian } \\
\cline { 3 - 4 } & & Laporan & Produk \\
\hline 1 & Bangun Ruang Sisi Lengkung & 80 & 82 \\
\hline 2 & Pemfaktoran dan Grafik & 85 & 88 \\
\hline 3 & Transformasi & 83 & 85 \\
\hline 4 & Peluang & 80 & 83 \\
\hline 5 & $\begin{array}{l}\text { Kesebangunan } \\
\text { Kekongruenan }\end{array}$ & 82 & 84 \\
\hline 6 & Bilangan Berpangkat & 80 & 82 \\
\hline 7 & Statistika & 80 & 82 \\
\hline \multicolumn{2}{|l|}{ Rata-rata persentase } & 81 & 84 \\
\hline
\end{tabular}

Pembelajaran workshop matematika dalam mengembangkan alat peraga dengan menggunakan Project Based Learning membuat mahasiswa lebih kreatif. Mahasiswa dapat menggali ide dan gagasan dalam rangka mengembangkan alat peraga matematika dari bahan bekas pakai. Diharapkan bahan bekas pakai seperti kardus, kertas koran bekas, tutup botol, kotak catur bekas, dan lain-lain yang sudah tidak terpakai menjadi lebih bermanfaat dengan inovasi dari mahasiswa. Hal yang selama ini dianggap sebagai limbah ternyata dapat dimanfaatkan kembali. Jadi, bukan hanya inovasi alat peraga matematika saja tetapi sekaligus mengolah limbah sehingga tidak mencemari lingkungan. Selain itu, produk alat peraga matematika dengan bentuk dan warna yang beragam membuat siswa lebih tertarik dalam pembelajaran matematika karena perkembangan kognitif anak usia SMP berada pada tahap operasional konkret [18]. Penggunaan bahan bekas pakai dapat menghemat pengeluaran guru dalam pengadaan alat peraga.

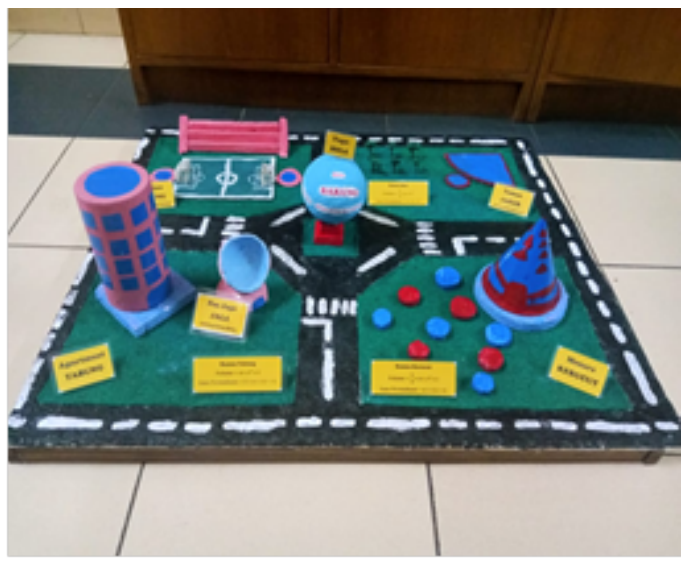

Gambar 1. Alat peraga bangun ruang sisi lengkung

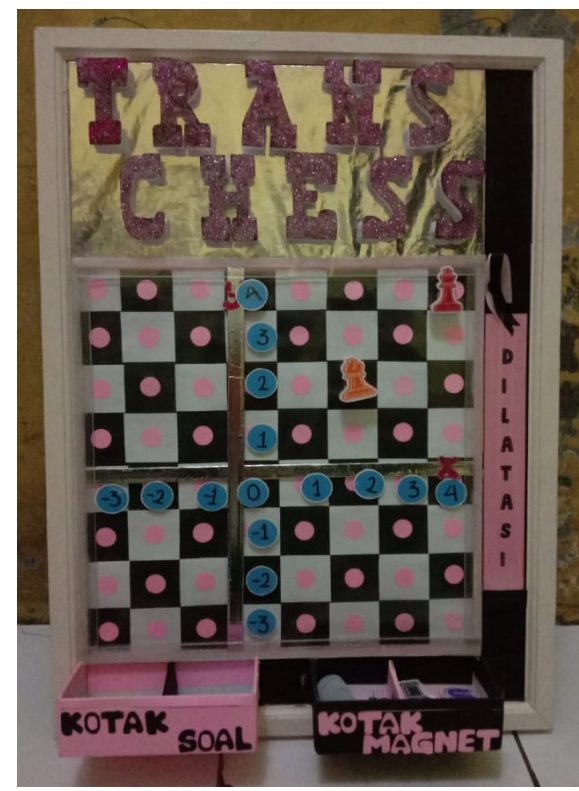

Gambar 2. Alat peraga transformasi

Melalui penerapan model pembelajaran Project Based Learning, mahasiswa merencanakan dan melaksanakan proyek, kemudian mereka merefleksi produk yang dihasilkan dari proyek tersebut untuk disusun dalam laporan akhir yang dipresentasikan secara berkelompok di kelas. Project Based Learning menekankan pendidikan yang memberi peluang pada sistem pembelajaran yang berpusat pada peserta didik/mahasiswa, secara kolaboratif dan mengintegrasikan masalah-masalah nyata dan praktis, pengajarannya efektif dalam membangun pengetahuan dan kreatifitas [19].

Berdasarkan tabel 2 pula, model pembelajaran Project Based Learning melatih mahasiswa memiliki kemampuan yang baik dalam mengkomunikasikan produk yang dihasilkan dari proyeknya. Ketujuh kelompok, semuanya menyajikan hasil proyek melalui presentasi yang menarik, sehingga suasana belajar menjadi lebih efektif. Situasi 
tersebut menimbulkan semangat di antara mereka, sehingga mereka terlibat dalam kegiatan tanya jawab untuk mengajukan pertanyaan, memberikan sanggahan, mengemukakan pendapat, dan berbagi informasi dengan tujuan untuk menambah pengetahuan mengenai pengembangan alat peraga matematika untuk kelas 9 SMP.

Berdasarkan hasil penelitian sebelumnya telah mendapatkan hasil bahwa penerapan Project Based Learning (PjBL) berhasil meningkatkan kinerja siswa selama pembelajaran [20]. Pembelajaran berbasis proyek memungkinkan mahasiswa memperluas wawasan pengetahuan dari mata kuliah produksi media dan alat peraga IPA. Pengetahuan yang diperoleh menjadi lebih berarti dan kegiatan pembelajaran menjadi lebih menarik, karena pengetahuan itu bermanfaat baginya untuk lebih mengapresiasi lingkungannya dengan memanfaatkan bahan bekas pakai, lebih memahami dan memecahkan masalah yang dihadapi dalam kehidupan sehari-sehari [21]. Dengan demikian dapat dikatakan bahwa pembelajaran berbasis proyek adalah sebuah pembelajaran yang relevan dengan melibatkan aspek lingkungan tempat mahasiswa berada dan belajar dengan melibatkan kreativitas yang ada dalam diri mahasiswa.

\section{KESIMPULAN}

Dari hasil penelitian yang telah dilakukan dapat disimpulkan bahwa kreativitas mahasiswa dalam menghasilkan alat peraga matematika sangat tinggi dengan nilai rata-rata laporan akhir 81 dan nilai rata-rata produk 84 , sehingga dapat disimpulkan bahwa pembelajaran dengan model pembelajaran Project Based Learning (PjBL) mampu mengembangkan kreativitas mahasiswa.

\section{DAFTAR PUSTAKA}

[1] R.T. Sari dan Siska Angreni, "Penerapan Model Pembelajaran Project Based Learning (PJBL) Upaya Peningkatan Kreativitas Mahasiswa," Varia Pendidikan, vol. 30, no. 1, pp. 79-83, 2018.

[2] M. I. Suarsana dan G. A. Mahayukti, "Pengembangan E-Modul Berorientasi Pemecahan Masalah Untuk Meningkatkan Keterampilan Berpikir Kritis Mahasiswa," Jurnal Pendidikan Indonesia, vol. 2, no. 2, pp. 264-275, 2013.

[3] A. A. Saefudin, "Pengembangan Kemampuan Berpikir Kreatif Siswa Dalam Pembelajaran Matematika Dengan Pendekatan Pendidikan Matematika Realistik Indonesia (PMRI)," Albidayah, vol. 4, no. 1, pp. 37-48, 2012

[4] Rahayu, "Pembelajaran Sains dengan Pendekatan Keterampilan Proses untuk Meningkatkan Hasil Belajar dan Kemampuan Berpikir Kreatif Siswa," Jurnal Pendidikan Fisika Indonesia, vol. 7, pp. 106110, 2011

[5] P. C. Tirtiana, "Pengaruh Kreativitas Belajar, Penggunaan Media Pembelajaran Powerpoint, dan Lingkungan Keluarga terhadap Hasil Belajar Mata Pelajaran Akuntansi pada Siswa Kelas X Akt SMK Negeri 2 Blora Tahun Ajaran 2012/2013 (Motivasi Belajar sebagai Variabel Intervenin," EEAJ, vol. 2, no. 2, pp. 15-23, 2013.

[6] T. P. Tridaya, dkk, "Meningkatkan Kemampuan Berpikir Kreatif Siswa dengan Pembelajaran Berbasis Masalah," Jurnal Pendidikan Matematika, vol. 1, no. 1, pp. 22-26, 2012.
[7] Y. Abidin, Desain Sistem Pembelajaran dalam Konteks Kurikulum. Bandung: PT. Refika Aditama, 2014.

[8] T. N. H. Yunianta, Rochmad dan A. Rusilowati, "Kemampuan Berpikir Kreatif Siswa pada Implementasi Project Based Learning dengan Peer and Self-assessment untuk Materi Segiempat Kelas VII SMPN RSBI 1 Juwana di Kabupaten Pati," in Seminar Nasional Matematika dan Pendidikan Matematika Jurusan Pendidikan Matematika FMIPA UNY, 2012.

[9] The George Lucas Educational Foundation. Instructional Module Project Based Learning. [Online]. http://www.edutopia.org/modules/PBL/whatpbl.php

[10] N. Sudjana, Dasar-dasar Proses Belajar Mengajar. Bandung: Sinar Baru Algensindo, 2009.

[11] A. Arsyad, Media Pembelajaran. Jakarta: PT. Raja Grafindo Persada, 2009.

[12] E. Estiningsih, Landasan Teknik Pengajaran Hitung SD. Yogyakarta: PPPG Matematika, 1994

[13] A. R. Lesh, "Applied Problem Solving in Early Mathematics Learning," Northwestern University, Unpublised working paper 1999.

[14] P. Blumenfeld, Soloway, E., Marx, R., Krajcik, J., Guzdial, M., \& Palincsar, A, "Motivating Project-based Learning: Sustaining the Doing, Supporting the Learning," Educational Psychologist, vol. 26, pp. 369-398.

[15] Sugiono, Metode Penelitian Kuantitatif Kualitatif dan $R \& D$. Bandung: Alfabeta, 2013.

[16] T. K. Santi, "Pembelajaran Berbasis Proyek (Project Based Learning) untuk Meningkatkan Pemahaman Mata Kuliah Fisiologi Tumbuhan," Jurnal Ilmiah PROGRESSIF, vol. 7, no. 21, pp. 74-83, 2011.

[17] R. T. Sari, "Pengembangan Perangkat Pembelajaran Berorientasi Pendidikan Karakter dalam Pembelajaran IPA SMK," Universitas Negeri Padang, Tesis 2012

[18] F. Baiq, "Pembelajaran Berbasis Proyek untuk Meningkatkan Kemampuan Berpikir Mahasiswa pada Mata Kuliah Mikrobiologi Pangan dan Industri," in Prosiding Seminar Nasional Pendidikan IPA, Semarang, 2011.

[19] Y. Doppelt, "Assessment Of Project Based Learning In A Mechatronics Context," Journal of Technology Education, vol. 16, no. 2, pp. 7-24, 2005.

[20] R. Schneider, Kracjik, J., Mark, R.W. \& Soloway, E, "Performance of Students in Project-Based Science Classroom on National Measure of Science Achievement," Journal of Research Science Teaching, vol. 39, no. 5, pp. 410-422, 2002.

[21] A. Widyatmoko dan S. D. Pamelasari, "'Pembelajaran Berbasis Proyek untuk Mengembangkan Alat peraga IPA dengan Memanfaatkan Bahan Bekas Pakai," Jurnal Pendidikan IPA Indonesia, vol. 1, no. 1, pp. 51-56, 2012. 